\title{
Kinetics and energetics of growth of the marine choanoflagellate Stephanoeca diplocostata
}

\author{
Richard J. Geider*, Barry S. C. Leadbeater \\ Department of Plant Biology, University of Birmingham, PO Box 363, Birmingham B15 2TT, England
}

\begin{abstract}
Growth kinetics and energetics of the marine, loricate choanoflagellate Stephanoeca diplocostata Ellis were investigated in batch cultures at a temperature of $18^{\circ} \mathrm{C}$. The increase of cell numbers was exponential, with no evidence for a lag phase upon subculturing from a growing culture into a fresh bacterial suspension. Subculturing from a stationary phase culture resulted in lag phases of up to $24 \mathrm{~h}$. A maximum growth rate of $1.9 \mathrm{~d}^{-1}$ was observed at a bacterial concentration of about $10^{8}$ bacteria $\mathrm{ml}^{-1}$. The half saturation constant for growth was $6.8 \times 10^{6}$ bacteria $\mathrm{ml}^{-1}$ Growth rate decreased to less than $0.5 \mathrm{~d}^{-1}$ at a concentration of $2.5 \times 10^{6}$ bacteria $\mathrm{ml}^{-1}$. Of the bacterial organic carbon ingested by $S$. diplocostata, it was estimated that $60 \%$ was used in respiration, $13 \%$ was egested as unassimilated particulate organic matter and $27 \%$ was used for growth.
\end{abstract}

\section{INTRODUCTION}

Phagotrophic flagellates are an important component of the marine nanoplankton (Sieburth 1979, Newell \& Linley 1984) and have been implicated as major consumers of suspended bacteria (Fenchel 1982c, Azam et al. 1983, Goldman 1984). The role of these organisms as either links or sinks for organic matter in marine food webs depends in large part on the efficiency with which prey biomass can be repackaged into particles which are accessible to larger filter-feeding zooplankton, and on the size difference between phagotrophic flagellates and their prey. The role of microflagellates as links has been advanced by Azam et al. (1983) and is based on high growth yields of protozoans (Calow 1977). However, because some phagotrophic flagellates can ingest prey of approximately their own size, Caron et al. (1985b) have advocated the role of microflagellates as sinks for organic carbon. Interest in the role of phagotrophic nanoflagellates in marine microbial ecosystems has led to laboratory investigations into their food requirements (Haas \& Webb 1979), and their growth kinetics and energetics (Kopylov et al. 1980, Fenchel 1982a, Sherr et al. 1983, Caron et al. 1985b, 1986, Rivier et al. 1985, Parslow et al. 1986).

\footnotetext{
- Present address: College of Marine Studies, University of Delaware, Lewes, Delaware 19958-1298, USA
}

Unfortunately, investigations into the bioenergetics of microbial phagotrophs in nature are fraught with technical difficulties (Hollibaugh et al. 1980, Taylor \& Sullivan 1984).

Choanoflagellates are an important group of nanoplanktonic flagellates and loricate species can be readily identified by light microscopy (Throndsen 1974). They have been identified as important components of marine nanoplankton, particularly in cold waters (Silver et al. 1980, Booth et al. 1982, Marchant 1985). They possess a distinctive circular collar surrounding a single flagellum (Throndsen 1974). Bacteria have been observed on the collar and within food vacuoles of choanoflagellates from natural populations (Leadbeater \& Manton 1974). Some species have been grown in axenic culture when high concentrations of dissolved organic matter have been used as an energy source (Gold et al. 1970). At the low concentrations of dissolved organic matter normally encountered in the sea, choanoflagellates are likely to feed on particulate matter (Haas \& Webb 1979). Whereas Fenchel (1986) considers the group to be exclusively bactivorous due to physical limitations on the size of particles which can be ingested, Laval (1971) observed that choanoflagellates could also prey on chroococcoid cyanobacteria. This paper considers the growth kinetics and energetics of the loricate choanoflagellate Stephanoeca diplocostata. 


\section{MATERIALS AND METHODS}

The choanoflagellate Stephanoeca diplocostata Ellis, originally isolated in 1976, has been maintained in culture at the University of Birmingham, England. It has been used in previous studies of ultrastructure, growth and silicon uptake dynamics (Leadbeater 1979, Leadbeater \& Davies 1984). S. diplocostata was rendered monoaxenic by treatment with an antibiotic mix (Hoshaw \& Rosowski 1973) and inundation with stationary phase pure culture of a marine pseudomonad. Culture medium for pseudomonad was prepared by adding 4 times the stock nutrients and vitamins for the modified ES medium of Harrison et al. (1980) to autoclaved seawater which had previously been filtered through a $0.45 \mu \mathrm{m}$ Millipore cellulose acetate membrane filter. Glucose, at a concentration of $50 \mathrm{mg} \mathrm{l}^{-1}$, served as the organic carbon source. With this glucose concentration, the bacterial yield was ca $95 \times 10^{6}$ cells $\mathrm{ml}^{-1}$. Dilutions of stationary phase bacterial cultures to final concentrations of 2.4 to $95 \times 10^{6}$ cells $\mathrm{ml}^{-1}$ were made with enriched seawater to examine the responses of growth rate and yield of $S$. diplocostata to bacterial numbers. Experimental incubations were conducted in darkness at a temperature of $18^{\circ} \mathrm{C} \pm 1 \mathrm{C}^{\circ}$

Estimates of the growth efficiency in terms of organic carbon were made using organic ${ }^{14} \mathrm{C}$ as a tracer. Bacteria were cultured in the medium described above with the addition of uniformly labelled ${ }^{14} \mathrm{C}$-glucose to a final activity of $10900 \mathrm{dpm} \mathrm{ml}^{-1}\left(0.05 \mathrm{uCi} \mathrm{ml}^{-1}\right)$. When in early stationary phase the bacteria, at a concentration of $93 \times 10^{6}$ cells $\mathrm{ml}^{-1}$, were diluted to $12 \times 10^{6}$, $22 \times 10^{6}$ and $41 \times 10^{6}$ cells $\mathrm{ml}^{-1}$. Then, $200 \mathrm{ml}$ aliquots from each dilution and the original undiluted culture were transferred to each of three $500 \mathrm{ml}$ Erlenmyer flasks. These were allowed to stand for $12 \mathrm{~h}$ prior to addition of Stephanoeca diplocostata to 2 of the 3 flasks, the third flask serving as a control. Concentrations of dissolved ( $\mathrm{DO}^{14} \mathrm{C}$ ) and particulate $\left(\mathrm{PO}^{14} \mathrm{C}\right)$ organic ${ }^{14} \mathrm{C}$ activity, and bacterial and microflagellate cell numbers were determined at $12 \mathrm{~h}$ intervals over a $110 \mathrm{~h}$ period. For determination of $\mathrm{PO}^{14} \mathrm{C}, 1 \mathrm{ml}$ aliquots were filtered through Whatman GF/F filters, rinsed with two $5 \mathrm{ml}$ aliquots of filtered seawater, and transferred to plastic minivials. Four ml of scintillation cocktail (Beckman Ready Value) were immediately added to each sample. Microscopic examination of the filtrate from GF/F filters indicated quantitative retention $\left(>99 \%\right.$ ) of bacteria. For determination of $\mathrm{DO}^{14} \mathrm{C}, 1 \mathrm{ml}$ aliquots of $\mathrm{GF} / \mathrm{F}$ filtered samples were transferred to standard glass scintillation vials, $100 \mu l$ of $1 \mathrm{~N} \mathrm{HCl}$ was added to the sample, and $\mathrm{CO}_{2}$ was allowed to purge for $24 \mathrm{~h}$. Then $10 \mathrm{ml}$ of scintillation cocktail (Beckman Ready Value) were added to each sample. Scintillation counting was done on a United Technologies Packard Tricarb 4530 scintillation counter. Quench correction was by the external standards method.

Epifluorescence microscopy using the DNA stain DAPI (Porter \& Feig 1980) was used to count bacteria and microflagellates collected on $0.2 \mu \mathrm{m}$ Nuclepore filters which had been previously stained with Irgalan black. Samples were preserved in 1\% glutaraldehyde in filtered seawater. Linear dimensions of Stephanoeca diplocostata were measured on projected photographic transparencies of cells mounted in glycerine jelly (Geider 1987). Linear dimensions of bacteria were measured on projected photographic transparencies of DAPI stained cells. Cell volumes were calculated as $V$ $=(\pi / 6)\left(s^{2} 1\right) ;$ where $s=$ length of the shortest axis in the field of view and $l=$ length of the longest axis, under the assumption that cell shape could be approximated by a prolate spheroid.

\section{RESULTS AND DISCUSSION}

\section{Growth kinetics}

A typical growth curve for Stephanoeca diplocostata is illustrated in Fig. 1. An exponentially growing culture was inoculated into a suspension containing $90 \times 10^{6}$ bacteria $\mathrm{ml}^{-1}$ at 00:00 h. A lag phase was not apparent, and growth proceeded exponentially at a rate of $0.074 \mathrm{~h}^{-1}\left(1.8 \mathrm{~d}^{-1}\right)$ for ca $70 \mathrm{~h}$. The transition from exponential to stationary phase was abrupt and stationary phase lasted for ca $5 \mathrm{~d}$, after which an exponential

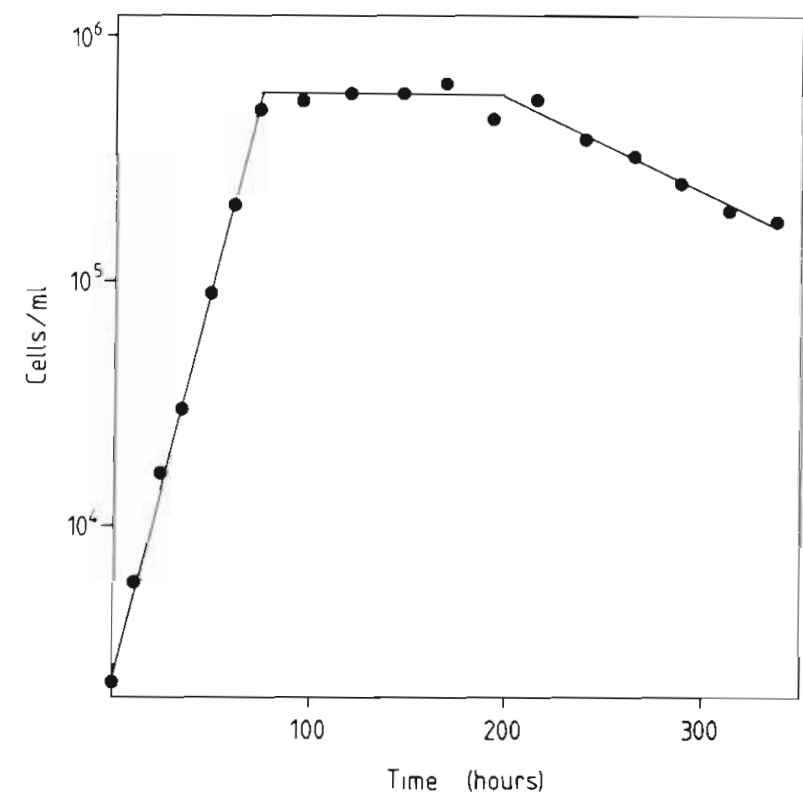

Fig. 1. Stephanoeca diplocostata. Growth curve in batch culture illustrating exponential, stationary and declining phases 
decline in numbers was observed. A lag phase can be avoided by subculturing $S$. diplocostata while still in exponential growth, but becomes evident with inocula from stationary phase cultures. The extent of the lag phase increased with the amount of time that the culture remained in stationary phase (Fig. 2) as has been noted previously for an Ochromonas sp. (Fenchel $1982 \mathrm{~b}$ ). The length of the lag phase was $14 \mathrm{~h}$ after $1 \mathrm{~d}$ in stationary phase, $19 \mathrm{~h}$ after $4 \mathrm{~d}$ in stationary phase, and $24 \mathrm{~h}$ after $11 \mathrm{~d}$ in stationary and declining phases of the growth curve.

The relationship between growth of Stephanoeca diplocostata and decline in bacterial numbers is illustrated in Fig. 3. A stationary phase bacterial culture was inoculated with $S$. diplocostata at $t=14: 00 \mathrm{~h}$. The concentration of flagellates increased by over 2 orders of magnitude as the total bacterial numbers declined by about an order of magnitude during the first $70 \mathrm{~h}$ following inoculation. Aggregation of bacteria into clumps of several hundred cells occurred in cultures inoculated with $S$. diplocostata, but was not observed in control cultures containing only bacteria. Clumping makes bacteria unavailable to $S$. diplocostata, and very high concentrations of total bacteria remained in the experimental flasks after $S$. diplocostata entered stationary phase. However, the concentration of unattached bacteria decreased to under $10^{5} \mathrm{ml}^{-1}$. Total bacteria could not always be accurately enumerated, particularly in stationary phase $S$. diplocostata cultures, because of clumping. As a consequence, reciprocal curves of growth of $S$. diplocostata and the decline of bacterial numbers were only obtained in 4 experi-

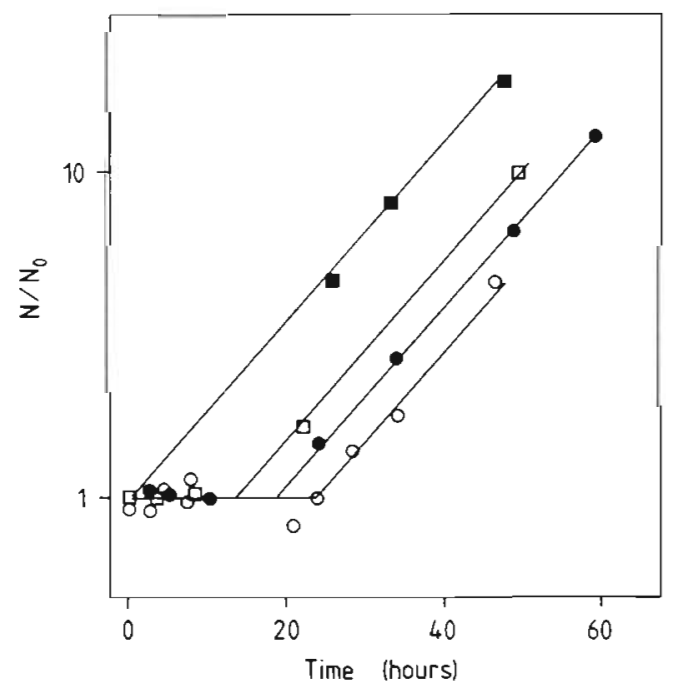

Fig. 2. Stephanoeca diplocostata. Duration of lag phase in batch cultures as a function of length of time of innoculum in stationary phase. $\mathrm{N} / \mathrm{N}_{0}$ is concentration of $\mathrm{S}$. diplocostatum relative to that obtained immediately after transfer to fresh. bacterial suspension. Amount of time in stationary phase varied from $0 \mathrm{~d}(\square)$, to $1 \mathrm{~d}(\square)$, to $4 \mathrm{~d}(\bullet)$, to $11 \mathrm{~d}(0)$

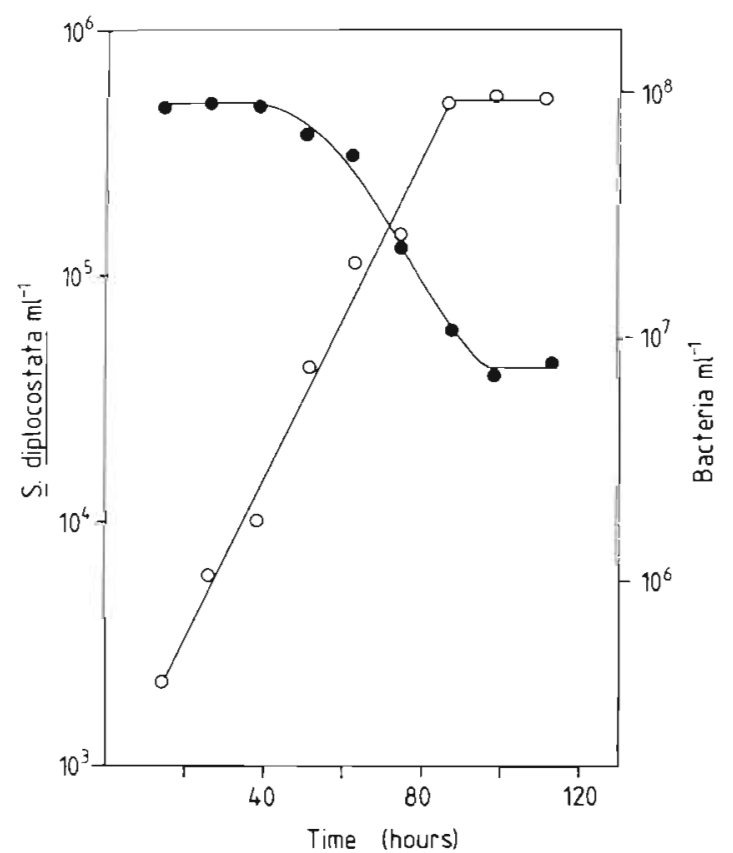

Fig. 3. Stephanoeca diplocostata. Growth $(0)$ and decline of bacterial numbers $(\bullet)$ in batch culture

ments. Initial and final bacterial numbers, growth rates for $S$. diplocostata and growth yields from these experiments are summarized in Table 1 . The growth rate of $S$. diplocostata increased with increasing initial concentrations of bacteria. The conversion of bacterial cells into flagellate cells was constant, within the limits of experimental error, with an average requirement of 130 bacteria consumed for each $S$. diplocostata produced.

Additional experiments were undertaken to determine the growth rate and final concentration of $S$. diplocostata as a function of the initial bacterial concentration. These measurements, together with those summarized in Table 1, are illustrated in Fig. 4. Growth rate was a saturating function of bacterial concentration, decreasing to $0.018 \mathrm{~h}^{-1}\left(0.45 \mathrm{~d}^{-1}\right)$ at an initial bacterial concentration of $2.4 \times 10^{6} \mathrm{ml}^{-1}$.

Table 1. Bacterial numbers and growth rate and yield of Stephanoeca diplocostata

\begin{tabular}{|c|c|c|c|c|}
\hline \multirow[t]{2}{*}{$\begin{array}{l}\text { Experi- } \\
\text { ment }\end{array}$} & \multicolumn{2}{|c|}{$\begin{array}{l}\text { Bacterial numbers } \\
\left(10^{6} \text { bacteria } \mathrm{ml}^{-1}\right)\end{array}$} & \multirow{2}{*}{$\begin{array}{l}\text { Growth } \\
\text { rate }\left(\mathrm{h}^{-1}\right) \\
\text { mean }(\mathrm{SD})^{\mathrm{a}}\end{array}$} & \multirow[t]{2}{*}{$\begin{array}{r}\text { Yield (cells } \\
\text { bacterium }{ }^{-1} \text { ) }\end{array}$} \\
\hline & Initial & Final & & \\
\hline 1 & 12.3 & 2.0 & $0.053(0.004)$ & 0.0081 \\
\hline 2 & 23.0 & 2.3 & $0.058(0.003)$ & 0.0071 \\
\hline 3 & 40.0 & 4.0 & $0.064(0.002)$ & 0.0082 \\
\hline 4 & 90.0 & 8.0 & $0.074(0.004)$ & 0.0064 \\
\hline
\end{tabular}



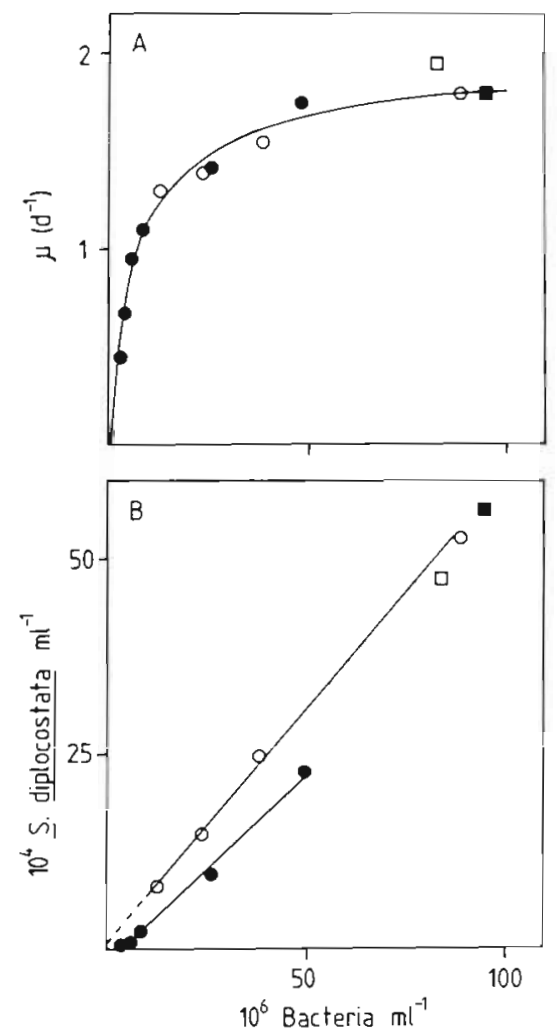

Fig. 4. Stephanoeca diplocostata. (A) Growth rate as a function of initial bacterial concentration in batch cultures. Various symbols refer to different sets of experiments (see text for details). Curve indicates nonlinear least squares fit to Eq. (1). (B) Final concentration of $S$. diplocostata as function of initial bacterial numbers. Note consistently lower final yield of $S$. diplocostata observed in one set of experiments $(\bullet)$ which may have been due to extensive aggregation of bacteria

The final concentrations of Stephanoeca diplocostata was a linear function of the initial bacterial concentration (Fig. 4); however, there was considerable variability associated with this relationship. One set of observations (indicated by filled circles in Fig. 4) yielded a consistently lower final concentration of $S$. diplocostata which was probably due to a large amount of bacterial aggregation which reduced the availability of unattached bacteria.

Observations of growth rate and initial bacteria concentrations were fitted to a hyperbolic function of the same form as Michaelis-Menten enzyme kinetics (Eq. 1) using nonlinear regression analysis

$$
\mu(B)=\mu_{m} B /(\mathrm{K}+B)
$$

where $\mu(B)=$ growth rate of Stephanoeca diplocostata; $B=$ initial bacterial concentration; $\mu_{m}=$ maximum growth rate; $\mathrm{K}=$ the half-saturation constant. Values of $\mu_{m}=1.9 \pm 0.06 \mathrm{~d}^{-1}$ and $\mathrm{K}=6.8 \pm 0.9 \times 10^{6}$ bacteria $\mathrm{ml}^{-1}$ were obtained for the coefficients of Eq. (1). The maximum growth rate of $1.9 \mathrm{~d}^{-1}$ is considerably higher than previously reported values for $S$. diplocostata (Leadbeater \& Davies 1984). Differences in culture conditions and the concentrations or type of prey bacteria may account for the higher growth rates in the present study. The numerical value of $\mathrm{K}$ obtained for $S$. diplocostata in this study is similar to values obtained by other investigators for other bactivorous microflagellates (Fenchel 1982c, Rivier et al. 1985). Thus, S. diplocostata does not appear to differ greatly from other microflagellates in its requirements for bacteria.

Following Fenchel (1980), the bacterial uptake rate can be related to $\mu$ through the yield:

$$
U(B)=\mu(B) / Y
$$

where $U(B)=$ rate of ingestion of bacteria by Stephanoeca diplocostata; $Y=$ number of flagellates produced per bacterium ingested during the exponential growth phase. The ratio of $S$. diplocostata produced per bacterium ingested averaged 0.0075 in stationary phase cultures (Table 1). Because $S$. diplocostata undergoes one division following exhaustion of its food supply, resulting in a $50 \%$ reduction in cell volume, this value of yield must be divided by 2 in order to be applicable to the exponential phase of the growth curve. Thus, the maximum uptake rate of bacteria by $S$. diplocostata during exponential growth is $U_{m}(B)=(1.9$ $\left.\mathrm{d}^{-1}\right) / 0.0037=510 \mathrm{~d}^{-1}$. Of more use in comparing filtering rates of different organisms is the rate at which a volume of water is stripped of particles. This rate has units of volume cleared per cell ( $\left.\mathrm{ml} \mathrm{cell}{ }^{-1}\right)$ and is referred to as the clearance. The maximum clearance is found when bacterial concentration limits the feeding rate of S. diplocostata. Following Fenchel (1980), and assuming that bacteria are uniformly distributed in the experimental flasks, the maximum clearance is given by:

$$
F_{m}=U_{m} / \mathrm{K}
$$

A. value of $F_{m}=\left(510\right.$ cells $\left.d^{-1}\right) /\left(6.8 \times 10^{6}\right.$ cells ml $\left.\mathrm{m}^{-1}\right)=$ $7.4 \times 10^{-5} \mathrm{ml} \mathrm{d}^{-1}$ is thus obtained for $S$. diplocostata. Given an average cell volume in exponentially growing cultures of $20 \mu \mathrm{m}^{3}$, a maximum clearance of $3.8 \times 10^{6}$ body volumes $\mathrm{d}^{-1}\left(1.6 \times 10^{5} \mathrm{~h}^{-1}\right)$ is calculated. This value falls within the range given by Fenchel (1982a) for 6 other flagellate species.

From Fig. 4A, it can be seen that the growth rate of Stephanoeca diplocostata extrapolates to zero as the concentration of bacteria decreases to zero. Fenchel (1982a) also observed that the growth rates for several other heterotrophic flagellates extrapolated to zero at zero bacteria. In contrast, Rivier et al. (1985) found threshold bacterial concentrations, below which the growth of a Pseudobodo sp. did not occur, of $\mathrm{ca} 10^{6}$ to $10^{7}$ bacteria $\mathrm{ml}^{-1}$

Concentrations of marine bacteria typically do not 
exceed $10^{6} \mathrm{ml}^{-1}$ in ocean waters (Sieburth et al. 1978). At this concentration the extrapolated growth rate for Stephanoeca diplocostata based on Eq. (1) is only $0.24 \mathrm{~d}^{-1}$. Similar, low growth rates can be calculated for other phagotrophic flagellates from data presented by Fenchel (1982a). Estimated growth rates based on laboratory experiments may exceed in situ growth rates because bacteria from surface waters are typically much smaller than bacteria from laboratory cultures. A much larger number of small cells may need to be ingested to provide the same food intake as a small number of large cells. In addition, phagotrophic flagellates may not graze efficiently on the very smallest bacteria. Andersson et al. (1986) demonstrated that optimal bacterial sizes for utilization by an Ochromonas sp. exceeded $0.25 \mu \mathrm{m}^{3}$, with negligible grazing at bacterial cell volumes under $0.15 \mu \mathrm{m}^{3}$. These results suggest that heterotrophic flagellates cannot control bacterial number in situ unless the growth rate of bacterial is also low.

It may be dangerous to extrapolate from observations on laboratory cultures of heterotrophic flagellates, which may require higher than 'normal' bacterial concentrations, to processes which may operate in the sea. For example, Fenchel's (1980) conclusion that ciliates could not utilize the low concentrations of bacteria available in the sea has recently been challenged (Sherr \& Sherr 1987). With regard to heterotrophic flagellates, however, Landry et al. (1984) recently concluded from observations of only modest growth in a relatively eutrophic bay, that growth in the oligotrophic gyres must be severely food limited. Active growth of heterotrophic flagellates may be limited to aggregates with higher bacterial abundance (Caron et al. 1985a), as has been suggested previously (Goldman 1984).

\section{Growth energetics}

Changes in particulate organic ${ }^{14} \mathrm{C}$ activity $\left(\mathrm{PO}^{14} \mathrm{C}\right)$ in experimental and control cultures from a typical experiment are illustrated in Fig. 5 . $\mathrm{PO}^{14} \mathrm{C}$ in the control flask decreased rapidly during the first $24 \mathrm{~h}$ of the experiment, then the rate of decline lessened. The change in $\mathrm{PO}^{14} \mathrm{C}$ between 36 and $120 \mathrm{~h}$ can be described by a straight line. Because the concentration of bacteria in the control flask was constant, this implies a constant cell-specific bacterial respiration rate. The decline of $\mathrm{PO}^{14} \mathrm{C}$ in flasks containing both Stephanoeca diplocostata and bacteria is illustrated by the solid symbols in Fig. 5. As the numbers of $S$. diplocostata in the experimental flask increased (Fig. 3), so did the divergence between $\mathrm{PO}^{14} \mathrm{C}$ in experimental and control flasks. At the end of the experiment, the experimental flasks contained only about one half the amount of the $\mathrm{PO}^{14} \mathrm{C}$ as did the control flasks. $\mathrm{DO}^{14} \mathrm{C}$ in control flasks did not change during the experiment equaling $17 \pm 1 \%$ of initial $\mathrm{PO}^{14} \mathrm{C}$ activitiy. $\mathrm{DO}{ }^{14} \mathrm{C}$ in the experimental flasks decreased to $81 \pm 2 \%$ of the initial value during the incubations. The decrease of $\mathrm{DO}^{14} \mathrm{C}$ equalled $8 \pm 1 \%$ of the final $\mathrm{PO}^{14} \mathrm{C}$ activity in the experimental flasks.

Carbon conversion efficiencies for growth of Stephanoeca diplocostata can be calculated from the observed $\mathrm{PO}^{14} \mathrm{C}$ time series. Initially, all of the $\mathrm{PO}^{14} \mathrm{C}$ was present in bacteria, but as the incubation progressed and bacteria were grazed by $S$. diplocostata, there was a transfer of ${ }^{14} \mathrm{C}$ from the bacteria to the flagellate. There was also a transfer of carbon from the dissolved to the particulate pools as evidenced by the decline in $\mathrm{DO}^{14} \mathrm{C}$. To determine carbon conversion efficiencies it

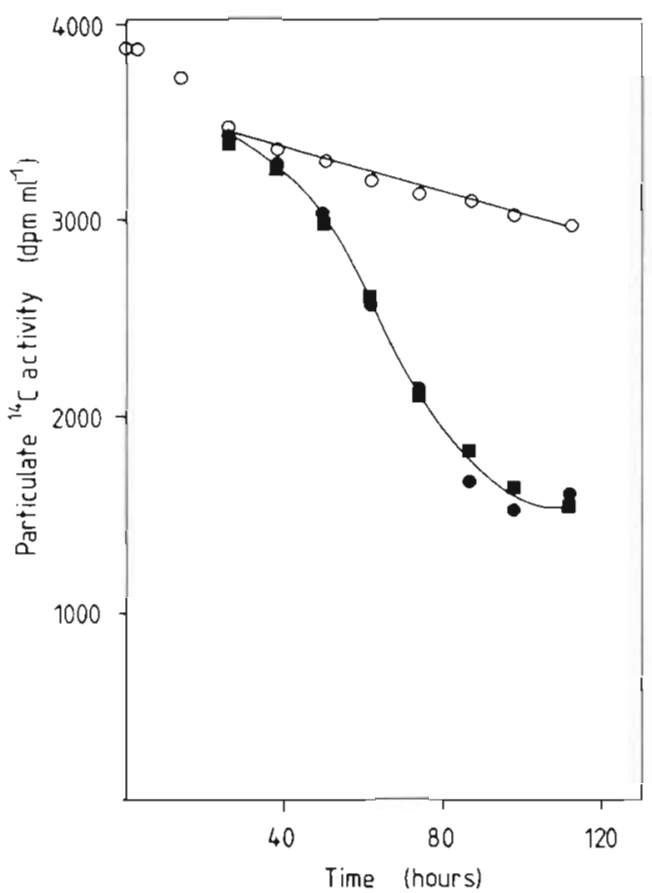

Fig. 5. Change of particulate organic ${ }^{14} \mathrm{C}$ activity with time in control $(\rho)$ and experimental $(\bullet)$ batch cultures. Data for experimental treatment are from same experiment as illustrated in Fig. 3

is necessary to calculate the ${ }^{14} \mathrm{C}$ activity in $S$. diplocostata, and the corresponding activity of ${ }^{14} \mathrm{C}$ in the ingested bacteria. The conversion efficiency cannot simply be taken as final $\mathrm{PO}^{14} \mathrm{C}$ divided by initial $\mathrm{PO}^{14} \mathrm{C}$, because corrections need to be made for the bacterial ${ }^{14} \mathrm{C}$ remaining in the culture, respiration of organic ${ }^{14} \mathrm{C}$ by bacteria, and conversion of $\mathrm{DO}^{14} \mathrm{C}$ to $\mathrm{PO}^{14} \mathrm{C}$ in the experimental flasks.

The ${ }^{14} \mathrm{C}$ activity of bacteria in the experimental flask at the end of the experiment was calculated as:

$$
B_{e} \cdot=B_{e} a_{c}
$$


where $B_{e}{ }^{*}={ }^{14} \mathrm{C}$ activity of bacteria $\left(\mathrm{dpm} \mathrm{ml} \mathrm{m}^{-1}\right) ; B_{e}=$ bacterial concentration (cells ml ${ }^{-1}$ ) in the experimental flask (designed by the subscript $e$ ) $; a_{c}={ }^{14} \mathrm{C}$ activity per bacterium (dpm cell ${ }^{-1}$ ) obtained for the control flask (designed by the subscript $c$ ). The amount of ${ }^{14} \mathrm{C}$ activity in $S$. diplocostata at the end of the experiment was calculated as:

$$
S_{e} \cdot=P_{e} \cdot-B_{e} \cdot
$$

where $S_{e}{ }^{\cdot}={ }^{14} \mathrm{C}$ activity of $S$. diplocostata; $P_{e}{ }^{\cdot}=$ total particulate ${ }^{14} \mathrm{C}$ activity $\left(\mathrm{dpm} \mathrm{ml}{ }^{-1}\right)$. This calculation assumes that ingested bacteria are assimilated with $100 \%$ efficiency (i.e. that egestion of unassimilated bacterial carbon is negligible). The validity of this assumption is considered later in this discussion. The carbon conversion efficiency $(\varepsilon)$ was calculated from:

$$
\varepsilon=S_{e}{ }^{*} /\left[P_{o}{ }^{*}-\delta \mathrm{DO}^{14} \mathrm{C}-B_{e}{ }^{*}-R\right]
$$

where $P_{0}{ }^{\circ}=$ initial ${ }^{14} \mathrm{C}$ activity of bacteria in the experimental flask; $\delta \mathrm{DO} \mathrm{O}^{14} \mathrm{C}=$ change in $\mathrm{DO}^{14} \mathrm{C}$ between the start and end of the experiment (for a decline in $\mathrm{DO}^{14} \mathrm{C}$, $\delta \mathrm{DO}{ }^{14} \mathrm{C}$ has a negative value); $R=$ a correction for loss of particulate ${ }^{14} \mathrm{C}$ activity due to respiration by bacteria in the experimental flask. Because the respiration rate in the control flask was constant between 36 and $110 \mathrm{~h}$ into the experiment (Fig.5), the respiration correction can be expressed as:

$$
R=B_{e} r T
$$

where $B_{e}=$ mean bacterial concentration in the experimental flask during the incubation; $r=$ respiration rate per bacterium (dpm cell-1 $\mathrm{h}^{-1}$ ) determined for the control flask; $T=$ duration of the incubation (h). Carbon conversion efficiencies $(\varepsilon)$ calculated from measurements made at 36 and $110 \mathrm{~h}$ into the experiment are summarized in Table 2. Average values of $\mathrm{PO}^{14} \mathrm{C}$ activity from duplicate experimental flasks were used in these calculations. Over the limited range of experimental conditions considered, the carbon conversion efficiency was independent of the initial bacterial concentration and growth rate of $S$. diplocostata with a mean value of $\varepsilon=0.40 \pm 0.02$ (i.e. $40 \%$ of the calculated decline in bacterial organic carbon reappeared in S. diplocostata).

Cell volumes of Stephanoeca diplocostata (Table 3) and bacteria were measured for samples from stationary phase cultures. Volumetric conversion efficiencies calculated from cell yields (Table 1) and cell volumes are given in Table 3 . The yield by volume of $S$. diplocostata growing on bacteria was only $0.27 \pm 0.04$ (i.e. $27 \%$ of the volume of ingested bacteria appeared as flagellate volume). This value is significantly lower than the carbon conversion efficiency calculated above. Fenchel (1982a) also reported volumetric conversion efficiencies for growth of microflagellates on
Table 2. Stephanoeca diplocostata. Calculation of carbon con-

\begin{tabular}{|c|c|c|c|c|c|c|}
\hline \multirow{2}{*}{$\begin{array}{l}\text { Experi- } \\
\text { ment }\end{array}$} & \multicolumn{5}{|c|}{ Organic ${ }^{14} \mathrm{C}$ activity $\left(\mathrm{dpm} \mathrm{ml}^{-1}\right)$} & \multirow{2}{*}{$\begin{array}{c}\text { Efficiency } \\
\varepsilon\end{array}$} \\
\hline & $P_{0} \cdot$ & $B_{e}$ & $S_{e} \cdot$ & $R$ & $\delta D O^{14} \mathrm{C}$ & \\
\hline 1 & 341 & 71 & 96 & 39 & 15 & 0.39 \\
\hline 2 & 700 & 81 & 222 & 54 & 24 & 0.38 \\
\hline 3 & 1575 & 141 & 534 & 118 & 54 & 0.39 \\
\hline 4 & 3318 & 282 & 1246 & 234 & 107 & 0.43 \\
\hline
\end{tabular}
version efficiency for growth on ${ }^{14} \mathrm{C}$ labelled bacteria. See text and Eq. (3) for details

Table 3. Stephanoeca diplocostata. Volume and biomass of stationary phase and efficiency of conversion of bacterial cell volume into flagellate call volume. Yield by volume was calculated from cell yields given in Table $1, S$. diplocostata cell volumes given in this table and bacterial cell volume of 0.28 $\mu \mathrm{m}^{3}$ cell $^{-1}$ measured in control flasks at end of experiment

\begin{tabular}{|cccc|}
\hline $\begin{array}{c}\text { Experi- } \\
\text { ment }\end{array}$ & $\begin{array}{c}\text { Volume } \\
\left(\mu \mathrm{m}^{3} \mathrm{cell}^{-1}\right) \\
\text { mean } \pm \mathrm{SD}^{\mathrm{a}}\end{array}$ & $\begin{array}{c}\text { Biomass } \\
\left(\mathrm{pg} \mathrm{C} \text { cell }^{-1}\right)\end{array}$ & $\begin{array}{c}\text { Yield by volume } \\
\left(\mu \mathrm{m}^{3} \mu \mathrm{m}^{-3}\right)\end{array}$ \\
\hline 1 & $7.8 \pm 2.2$ & 2.1 & 0.22 \\
2 & $11.3 \pm 3.2$ & 2.8 & 0.28 \\
3 & $10.9 \pm 3.4$ & 3.3 & 0.32 \\
4 & $11.6 \pm 3.8$ & 4.3 & 0.26 \\
aSD: standard deviation of mean & \\
\hline
\end{tabular}

bacteria which were lower than the carbon conversion efficiencies and Caron et al. (1985b) observed that volumetric yields were lower than carbon yields in Paraphysomonas imperforata feeding on bacteria and/ or diatoms.

Egestion of organic matter as particulate detritus was invoked by Caron et al. (1985b) as an explanation for the difference in carbon and volumetric conversion efficiencies. If a significant production of detritus occurred in our experiments, then the calculated carbon conversion efficiencies given in Table 2 will be overestimated. In order to examine this possibility, the cell carbon content of stationary phase Stephanoeca diplocostata was calculated from

$$
C=(1 / f)\left(S_{e} \cdot / S_{e}\right)
$$

where $C=$ cell organic carbon content $\left(\mathrm{pg} \mathrm{C} \mathrm{cell}^{-1}\right) ; f=$ specific activity of carbon ( $\mathrm{dpm} \mathrm{pg}^{-1}$ ) in the growth medium; and $S_{e}=$ concentration of $S$. diplocostata in the stationary phase culture (cells $\mathrm{ml}^{-1}$ ). A value of $f=$ $5.45 \times 10^{-4} \mathrm{dpm} \mathrm{pg}^{-1} \mathrm{C}$ was obtained from the concentration of glucose $\left(50 \mathrm{mg} \mathrm{l}^{-1}\right)$ and the ${ }^{14} \mathrm{C}$ activity (10900

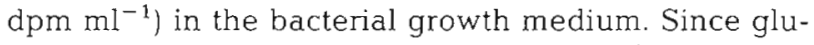
cose is $40 \%$ carbon by weight, $20 \mathrm{mg}^{-1}$ of organic carbon equalled $10900 \mathrm{dpm}$ of ${ }^{14} \mathrm{C}$ activity.

Calculated cell carbon contents ranged from 2.1 to 
$4.3 \mathrm{pg} \mathrm{C}$ cell $^{-1}$ in stationary phase cultures. Cell carbon content covaried with cell volume, giving a mean ratio of $0.30 \pm 0.05 \mathrm{pg} \mathrm{C} \mathrm{m}^{-3}$. This value is higher than expected on the basis of the relation between cell volume and carbon contents in microalgae. For example, a value of $0.22 \mathrm{pg} \mathrm{C} \mathrm{mm}^{-3}$ is obtained for Stephanoeca diplocostata from equations given by Eppley et al. (1970). This comparison suggests that the $\mathrm{PO}^{14} \mathrm{C}$ activity associated with $S$. diplocostata has been overestimated by 1.36 times, and that the carbon conversion efficiency should be readjusted downward from 40 to $29 \%$. This latter value is not significantly different from the volumetric conversion efficiency calculated previously. Alternatively, shrinking of $S$. diplocostata during fixation with glutaraldehyde, as has been noted for other microflagellates (Borsheim \& Bratbak 1977), could have led to an underestimate of cell volume. However, we have not noted any significant degree of shrinkage in glutaraldehyde-fixed cells. Shrinking is likely to present more of a problem in those species possessing a flexible cytoskeleton than in the collared flagellates which appear to have a fairly rigid microtubular cytoskeleton (Leadbeater 1983).

Assuming that the volumetric conversion efficiency accurately reflects the transfer of organic carbon from bacteria to Stephanoeca diplocostata, then a carbon budget for growth can be tentiatively advanced. Ingested organic matter can be used for growth or respiration, or may be egested

$$
I=G+R+E
$$

where $I=$ ingested organic carbon; $G=$ organic carbon used for growth; $R=$ loss of organic carbon to respiration; $E=$ egested organic carbon. Following Calow (1977), the gross growth efficiency is defined as $G / I$ and the net growth efficiency is defined as $G /(I-E)$. Of the bacterial organic carbon ingested by $S$. diplocostata, $60 \%$ is lost to respiration, $13 \%$ is egested and $27 \%$ is used for growth. Thus, a gross growth efficiency of $27 \%$, and a net growth efficiency of $31 \%$ are calculated. These values for $S$. diplocostata are on the low side of data available from the literature for other flagellates. Kopylov et al. (1980) measured a gross growth efficiency of ca $18 \%$ and net growth efficiencies of 60 to $70 \%$ in Parabodo attenuatus. Fenchel (1982a) measured gross growth efficiencies of $34 \%$ in Ochromonas sp. and $43 \%$ in Pleuromonas jaculans, but calculated net efficiencies of $60 \%$ for both species. Sherr et al. (1983) measured gross growth efficiencies which ranged from 24 to $45 \%$ in a Monas sp. fed on 4 different bacterial strains. Finally, Caron et al. (1985b) observed a gross growth efficiency of $44 \%$ and a net efficiency of $51 \%$ in Paraphysomonas imperforata feeding on bacteria or diatoms.

The conversion efficiencies for these flagellates can be compared with observations for other heterotrophs. A best possible conversion efficiency of 70 to $80 \%$ for heterotrophic cells was calculated by Calow (1977), but actual conversion efficiencies rarely achieve this theoretical limit. Within the Protozoa, conversion efficiencies range from $<10$ to $80 \%$ (Calow 1977). For example, many cilates have conversion efficiencies around $50 \%$ (Curds \& Cockburn 1971), although much lower values have also been observed (Calow 1977. Scott 1985). Low efficiencies may be associated with poor or non-ideal food quality (Scott 1985). It is possible that stationary phase cultures of a single bacterium do not provide the optimum food source for Stephanoeca diplocostata, although further investigations would be required to test this suggestion.

Our understanding of the structure of planktonic food chains is underpinned by the conventional assumption that transfer efficiencies between trophic levels range from 10 to $20 \%$ (Steele 1974, Parsons et al. 1977). That there is a large difference in growth efficiencies of protozoans and metazoans is another common tenet of current ecological thought amongst biological oceanographers (Azam et al. 1984, Fasham 1985). As pointed out by Copping \& Lorenzen (1980), however, these may be mistaken notions. In contrast to conventional expectations, growth efficiencies in small metazoans are often higher than in Protozoa (Calow 1977). In a variety of crustaceans, for example, gross growth efficiencies averaged $48 \pm 15 \%$, and net efficiencies averaged $65 \pm 22 \%$ (Calow 1977). Crustaceans are not exceptional among metazoans; equally high values of conversion efficiencies have been found for other invertebrates (Calow 1977). Within an oceanographic perspective, a recent carbon budget for the copepod Calanus pacificus feeding on phytoplankton revealed that $45 \%$ of ingested carbon was incorporated into the copepod with $27 \%$ lost as dissolved organic carbon, $4 \%$ egested as fecal material and $24 \%$ used in respiration (Copping \& Lorenzen 1980). Calculated values for gross growth efficiency of $45 \%$, and net efficiency of $65 \%$ in C. pacificus are as high or higher than comparable efficiencies summarized above for marine flagellates. Perhaps more attention should be given to the ecological implications of Calow's (1977) conclusion that Metazoa can achieve the best possible levels of efficiency predicted by theory and may, in this respect, be more efficient than isolated bacterial and protozoan cells.'

Acknowledgements. This work was supported by N.E.R.C. grant number GR3/5900.

\section{LITERATURE CITED}

Andersson, A., Larsson, U., Hagstrom, A. (1986). Size-selective grazing by a microflagellate on pelagic bacteria. Mar. Ecol. Prog. Ser. 33: 51-57 
Azam, F., Fenchel, T., Field, J. G., Gray, J.S., Meyer-Reil, L.A., Thingstad, F. (1983). The ecological role of watercolumn microbes in the sea. Mar Ecol. Prog. Ser. 10: $257-263$

Booth, B. C., Lewin, J., Norris, R. E. (1982). Nanoplankton species predomiant in the subarctic Pacific in May and June 1978. Deep Sea Res. 29: 185-200

Borsheim, K. V., Bratbak, G. (1987). Cell volume to cell carbon conversion factors for a bactivorous Monas sp. enriched from seawater. Mar. Ecol. Prog. Ser. 36: 171-175

Calow, P. (1977). Conversion efficiencies in heterotrophic organisms. Biol. Rev. 52: 385-409

Caron, D. A., Davis, P. G., Madin, L. P., Sieburth, J. McN. (1985a). Enrichment of microbial populations in macroaggregates (marine snow) from surface waters of the North Atlantic. J. mar. Res. 44: 543-565

Caron, D. A., Goldman, J. C., Andersen, O. K., Dennett, M. R. (1985b). Nutrient cycling in a microflagellate food chain: II. Population dynamics and carbon cycling. Mar. Ecol. Prog. Ser. 24: 243-254

Caron, D. A., Goldman, J. C., Dennett, M. R. (1986). Effect of temperature on growth, respiration, and nutrient regeneration by an omnivorous microflagellate. Appl. environ. Microbiol. 52: 1340-1347

Copping, A.E., Lorenzen, C. J. (1980). Carbon budget of marine phytoplankton-herbivore system with carbon-14 as a tracer. Limnol. Oceanogr 25: 873-882

Curds, C.R., Cockburn, A. (1971). Continuous monoaxenic culture of Tetrahymena pyriformnis, J. gen. Microbiol. 66: 95-108

Eppley, R.W., Reid, F.M.H., Strickland, J.D. (1970). The ecology of phytoplankton off La Jolla, California, in the period April through September 1967. Part III. Estimates of phytoplankton crop size, growth rate and primary production. Bull. Scripps Inst. Oceanogr. 17 33-42

Fasham, M. J.R. (1985). Flow analysis of materials in the marine euphotic zone. Can. Bull. Fish. Aquat. Sci. 213: 139-162

Fenchel, T. (1980). Suspension feeding in ciliates: Feeding rates and their ecological significance. Microb. Ecol. 6 : $13-25$

Fenchel, T (1982a). Ecology of heterotrophic microflagellates. II. Bioenergetics and growth. Mar Ecol. Prog. Ser. 8: $225-231$

Fenchel, T. (1982b). Ecology of heterotrophic microflagellates. III. Adaptations to heterogeneous environments. Mar. Ecol. Prog. Ser. 9: 25-34

Fenchel, T. (1982c). Ecology of heterotrophic microflagellates IV Quantitative occurrence and importance as bacterial consumers. Mar. Ecol. Prog. Ser 9: 35-42

Fenchel, T (1986). Protozoan filter feeding. Prog. Protistol. 1: $65-113$

Geider, R. J. (1987). An improved method for the observation. and enumeration of heterotrophic and photoautotrophic microplankton. J. exp. mar Biol. Ecol. 110: 19-25

Gold, K., Pfister, R. M., Liguori, V. R. (1970). Axenic cultivation and electron microscopy of two species of Choanoflagellida. J. Protozool. 17. 210-212

Goldman. J. C. (1984). Oceanic nutrient cycles. In: Fasham. M. J. (ed.) Flows of energy and materials in marine ecosystems. Plenum Press, New York, p. 137-170

Harrison, P. J., Waters, R. E., Taylor, F. J. R. (1980). A broad spectrum artificial seawater medium for coastal and open ocean phytoplankton. J. Phycol. 16: 28-35

Haas, L. W., Webb, K. L. (1979). Nutritional mode of several non-pigmented microflagellates from the York River Estuary, Virginia. J. exp. mar Biol. Ecol. 39: 125-134
Hollibaugh, J. T., Fuhrman, J. A., Azam, F. (1980). Radioactive labelling of natural assemblages of bacterioplankton for use in trophic studies. Limnol. Oceanogr 25: 172-181

Howshaw, R. W., Rosowski, J.R. (1973). Methods for microscopic algae. In: Stein. J. R. (ed.) Handbook of phycological methods. Culture methods and growth measurements. Cambridge University Press, Cambridge, p. 53-68

Kopylov, A. I., Mamayeva, T. I., Batsanin, S. F. (1980). Energy balance of the colorless flagellate Parabodo attenuatus (Zoomastigohora, Protozoa). Oceanology 20: 705-708

Landry, M. R., Haas, L. W., Fagerness, V. L. (1984). Dynamics of microbial plankton communities: experiments in Kaneohe Bay, Hawaii. Mar. Ecol. Prog. Ser 16: 127-133

Laval, M. (1971). Ultrastructure et mode de nutrition du choanoflagelle Salpingoeca pelagica, sp. nov. comparaison avec les choanocytes des spongiaires. Prototistologica 7 : 325-336

Leadbeater, B.S. C. (1979). Developmental studies on the loricate choanoflagellate Stephanoeca diplocostata Ellis. I. Ultrastructure of the non-dividing cell and costal strip production. Protoplasma 98: 241-262

Leadbeater, B. S. C. (1983). Distribution and chemistry of microfilaments in choanoflagellates, with special reference to the collar and other tentacle systems. Protistologica 14: $157-166$

Leadbeater, B.S. C., Davies, M.E. (1984). Developmental studies on the loricate choanoflagellate Stephanoeca diplocostata Ellis. III. Growth and turnover of silica, preliminary observations. J. exp. mar Biol. Ecol. 81. 251-268

Leadbeater, B.S.C., Manton, I. (1974). Preliminary observations on the chemistry and biology of the lorica in a collared flagellate (Stephanoeca diplocostata Ellis). J. mar. biol. Ass. U. K. 54: 269-276

Marchant, H.J. (1985). Choanoflagellates in the Antarctic marine food chain. In: Siegfried, W. R., Condy, P. R., Laws, R.W. (eds.) Antarctic nutrient cycles and food webs. Springer-Verlag, New York, p. 271-276

Newell, R. C., Linley, E.A.S. (1984). Significance of microheterotrophs in the decomposition of phytoplankton. estimates of carbon and nitrogen flow based on the biomass of plankton communities. Mar Ecol. Prog. Ser 16 : 105-119

Parslow, J. S., Doucette, G.J., Taylor, F.J. R., Harrison, P. J. (1986). Feeding by the zooflagellate Pseudobodosp. on the picoplanktonic prasinomonad Micromonas pusilla. Mar. Ecol. Prog. Ser. 29: 237-246

Parsons, T.R., Takahashi, M., Hargrave, B. (1977). Biological oceanographic processes. Pergamon Press, Oxford

Porter, K. G. Feig, Y. S. (1980). The use of DAPI for identifying and counting aquatic microflora. Limnol. Oceanogr. 25: 943-948

Rivier, A., Brownlee, D. C., Sheldon, R. W., Rassoulzadegan, F. (1985). Growth of microplankton: a comparative study of bactivorous zooflagellates and ciliates. Mar. microb. Food Webs, Paris 1: $51-60$

Scott, J.M. (1985). The feeding rates and efficiencies of a marine ciliate Strombidium sp., grown under chemostat steady-state conditions. J. exp. mar Biol. Ecol. 90: 81-95

Sherr, B.F., Sherr, E. B., Berman, T (1983). Grazing, growth, and ammonium excretion rates of a heterotrophic microflagellate fed with four species of bacteria. Appl. environ. Microbiol. 45: 1196-1201

Sherr, E. B., Sherr, B. F. (1987). High rates of consumption of bacteria by pelagic ciliates. Nature, Lond. 325: 710-711

Sieburth, J. McN. (1979). Sea microbes. Oxford University Press, Oxford 
Sieburth, J. McN., Smetacek, V., Lenz, J. (1978). Pelagic ecosystem structure: heterotrophic components of the plankton and their relationship to plankton size fractions. Limnol. Oceanogr 23: 1256-1263

Silver, M.W., Mitchell, J.G., Ringo, D. L. (1980). Siliceous nanoplankton. II. Newly discovered cysts and abundant choanoflagellates from the Weddell Sea, Antarctica. Mar. Biol. 58: 211-217
Steele, J.H. (1974). The structure of marine ecosystems. Blackwell Scientific Publications, Oxford

Taylor, G.T., Sullivan, C.W. (1984). The use of ${ }^{14} \mathrm{C}$-labelled bacteria as a tracer of ingestion and metabolism of bacterial biomass by microbial grazers. J. microb. Methods 3: 101-124

Throndsen, J. (1974). Planktonic choanoflagellates from North Atlantic waters. Sarsia 56: 95-122

This article was submitted to the editor; it was accepted for printing on May 26, 1988 